\title{
Development of Cassette-Type Water Treatment Package System for Emergencies
}

\author{
Ju-Suk An, Young Kyu Park, Ji Young Kim, Hyun Je Oh, and Jae-Roh Park
}

\begin{abstract}
The concept of water security has become an important social issue and the need to deploy emergency management systems of water supply has increased. This study observes the water sources available for emergency water supply and the characteristics of the pollutant leakage into each water source. The study also reviews suitable combinations of treatment processes based on the observations and presents a water treatment system for emergency water supply to manage such situations quickly. The cassette-type water treatment system developed in this study modularized the water treatment equipment manufactured by various manufacturers for a specific space so that the process could be structured selectively. Each module was designed to treat the water independently, and featured self-diagnosis, automatic operation, intelligent process selection, and communication functions. Compared to the existing emergency water supply systems, the presented system could intelligently select an operational process according to the raw water properties, and the power unit for self-generation was designed in the form of a cassette, so that it could operate for $2.0 \mathrm{~h}$ or longer, even under the condition of no power supply. Therefore, it could be used in case of not only a natural disaster but also an interruption of the water service.
\end{abstract}

Index Terms-Cassette-type, emergency, module, water treatment package.

\section{INTRODUCTION}

\section{A. Purpose of Study}

The Korean Government introduced the special disaster area declaration policy to effectively address and restore heavy damages from a prolonged flooding (more than 10 days) by torrential downpours in a Gyeongnam area, during August 4-11, 2002 [1]. Among the special disaster areas declared until now, no. 3 typhoon Ewiniar caused damage through torrential downpours for the longest period - from July 9 to 29,2006 - and the infrastructure did not function adequately during that period [2].

As such, the concept of water security has become an important social issue, and the need to deploy an emergency management system of water supply has increased. Because the existing centralized water supply systems perform poorly during disaster periods, water treatment systems that can quickly supply water to the affected areas in case of an emergency need to be developed [3].

This study observes the water sources available for emergency water supply and the characteristics of the pollutant leakage into each water source. The study also

Manuscript received April 15, 2014; revised June 18, 2014.

The authors are with the Korea Institute of Construction Technology (KICT), 283, Goyangdae-Ro, Ilsanseo-Gu, Goyang-Si, Gyeonggi-Do, 411-712, Korea (e-mail: jusuk@kict.re.kr, ykpark@kict.re.kr, jykim@kict.re.kr, hjoh@kict.re.kr,jrpark@kict.re.kr). reviews suitable combinations of treatment processes based on the observations and presents a water treatment system for emergency water supply and a quick management of such situations.

\section{B. Scope of Study}

Based on how a disaster occurs, it can be categorized into manmade disasters, caused by human errors, and natural disasters, caused by natural phenomena.

Fig. 1 shows that 303,707 cases of manmade disasters were tabulated by central and municipal governments in 2012, an increase of 16,858 cases $(5.8 \%)$ over the previous year; these caused 383,129 human casualties, an increase of 17,182 people (4.7\%), according to the Disaster Almanac. Disasters caused by traffic accidents, fire, and falling constituted 277,024 cases or $91.3 \%$ of the total [4].

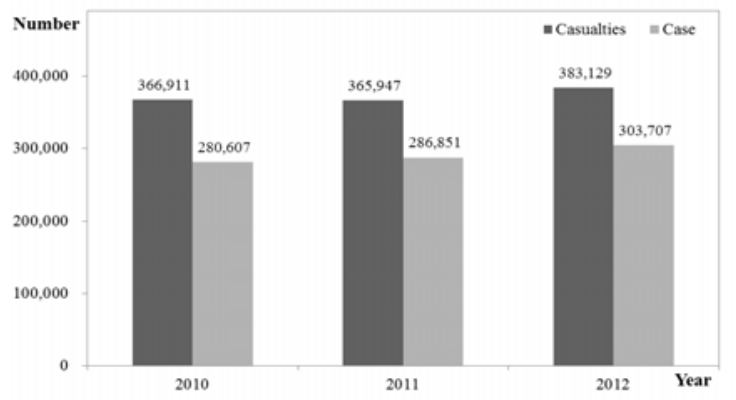

Fig. 1. Number of casualties and cases of manmade disasters over 3 years.

However, as Table I shows, it might not be appropriate to consider that the measures of emergency water supply are urgently required for manmade disasters because they mostly involve traffic accidents, fires, and human casualties and thus do not have long recovery periods [5]. On the other hand, natural disasters have relatively long recovery periods, disabling of social infrastructures such as water treatment facilities, and thus, require emergency water supply [6].

TABLE I: NuMBER OF CASUALTIES AND CASES BY TYPES OF MANMADE DISASTERS

\begin{tabular}{lccc}
\hline \multicolumn{1}{c}{$\begin{array}{c}\text { Type of } \\
\text { manmade disasters }\end{array}$} & $\begin{array}{c}\text { Casualties } \\
\text { (persons) }\end{array}$ & Cases & Ratio (\%) \\
\hline Road traffic accidents & 349,957 & 223,656 & 73.64 \\
Fire accidents & 2,213 & 43,249 & 14.24 \\
Bicycle accidents & 6,360 & 6,419 & 2.11 \\
Climbing accidents & 4,934 & 6,020 & 1.98 \\
Drowning accidents & 2,171 & 3,929 & 1.29 \\
Farm machinery & 2,043 & 2,076 & 0.68 \\
accidents & 557 & 557 & 0.18 \\
Electrical accidents & 241 & 402 & 0.13 \\
Collapse accidents & 136 & 130 & 0.04 \\
Railway accidents & 14,378 & 17,269 & 5.69 \\
Others. & & & \\
\hline \hline
\end{tabular}

Therefore, this study considered only natural disasters and 
particularly the ones that frequently occur in Korea, such as typhoons, flooding, drought, and heavy snowfall. Additionally, interruption of water services is also considered because it could result in financial losses for industrial complexes and thus necessitate supply of emergency water until their own water facilities are restored.

\section{PROCESS SELECTION}

\section{A. Natural Disaster Trend Analysis}

The data on natural disasters during 2001-2010 indicate the average damage caused by different phenomena in the decreasing order of scale as - typhoon, torrential rain, heavy snowfall, and others. Snowstorms caused the most damage in January and February, heavy snowfalls in March and December, and heavy rains and typhoons in June through September. The damage incident rate of heavy rains was the highest followed by that of typhoons [7]. Furthermore, according to the water service statistics by the Ministry of Environment, as shown in Table II, a total of 27,013 water service interruptions for 54,056 h occurred in 2011, representing approximately $2.0 \mathrm{~h}$ per case on average [8].

\begin{tabular}{lccc}
\multicolumn{4}{c}{ TABLE II: MONTHLY WATER SERVICE INTERRUPTION STATS $(2011)$} \\
\hline \hline Jan. & $1,258(1,642 \mathrm{~h})$ & $2,938(2,609 \mathrm{~h})$ & $4,196(4,251 \mathrm{~h})$ \\
Feb. & $1,178(1,763 \mathrm{~h})$ & $1,684(1,929 \mathrm{~h})$ & $2,862(3,692 \mathrm{~h})$ \\
Mar. & $1,117(2,753 \mathrm{~h})$ & $1,304(1,526 \mathrm{~h})$ & $2,421(4,279 \mathrm{~h})$ \\
Apr. & $968(3,894 \mathrm{~h})$ & $902(1,218 \mathrm{~h})$ & $1,870(5,112 \mathrm{~h})$ \\
May & $1,045(4,522 \mathrm{~h})$ & $951(1,308 \mathrm{~h})$ & $1,996(5,830 \mathrm{~h})$ \\
June & $997(4,120 \mathrm{~h})$ & $1,018(1,256 \mathrm{~h})$ & $2,015(5,375 \mathrm{~h})$ \\
July & $858(3,149 \mathrm{~h})$ & $960(1,547 \mathrm{~h})$ & $1,818(4,696 \mathrm{~h})$ \\
Aug. & $853(2,886 \mathrm{~h})$ & $1,031(1,254 \mathrm{~h})$ & $1,884(4,141 \mathrm{~h})$ \\
Sep. & $839(3,202 \mathrm{~h})$ & $1,000(1,198 \mathrm{~h})$ & $1,839(4,400 \mathrm{~h})$ \\
Oct. & $922(3,724 \mathrm{~h})$ & $1,015(1,248 \mathrm{~h})$ & $1,937(4,972 \mathrm{~h})$ \\
Nov. & $970(2,724 \mathrm{~h})$ & $1,081(1,294 \mathrm{~h})$ & $2,051(4,018 \mathrm{~h})$ \\
Dec. & $906(1,843 \mathrm{~h})$ & $1,218(1,436 \mathrm{~h})$ & $2,124(3,279 \mathrm{~h})$ \\
\hline Total & $11,911(36,222 \mathrm{~h})$ & $15,102(17,824 \mathrm{~h})$ & $27,013(54,046 \mathrm{~h})$ \\
\hline \hline
\end{tabular}

\section{B. Characteristics of Sources of Emergency Raw Water}

Water treatment systems for supplying emergency water must obtain a source of water in the field and supply a suitable quantity of water for the purpose.

Although village water works and small water supply facilities can be used in case of water service interruption, groundwater and valley water are the mostly used sources. Spring water, personal wells, surface water, and river water are sometimes used as well [9]. Because the water sources for the emergency water treatment system are expected to be similar to the above sources, we reviewed the water quality of river water and groundwater. Table III shows the turbidity, algae, microorganisms, and levels of organic/inorganic pollutant materials, which are the main factors considered in a water treatment process.

In Korea, the river water quality is managed in terms of eight items ( $\mathrm{pH}$, biochemical oxygen demand (BOD), chemical oxygen demand (COD), suspended solids (SS), dissolved oxygen (DO), coliform count, total nitrogen (T-N), total phosphorous (T-P)) related to living environmental standard and nine items $\left(\mathrm{Cd}, \mathrm{As}, \mathrm{CN}, \mathrm{Hg}, \mathrm{PO}_{4}{ }^{3-}, \mathrm{Pb}^{2+}, \mathrm{Cr}^{6+}\right.$, polychlorinated biphenyls (PCB), and $\mathrm{ABS}$ ) related to human health protection standards. Of these, BOD and COD that help evaluate the concentrations of organic materials, and $\mathrm{T}-\mathrm{N}$ and T-P, which are the eutrophication indices of enzymes, are used as the key index factors. Although river water may contain a nominal amount of pollutants in terms of organic materials and nutriments, it can still be used for recreational purposes and for living purposes. The water quality generally changes during emergencies such as flooding or drought. During a flood, non-point pollutants such as soil and muck from upstream may flow to create high turbidity conditions, while concentration of organic materials increases due to a sudden decrease in river flux during a drought.

TABLE III: RuNOFF CHARACTERISTICS OF POLLUTANTS ACCORDING TO WATER SOURCE

\begin{tabular}{|c|c|c|c|c|c|}
\hline \multicolumn{2}{|c|}{ Water Source } & Turbidity & Algae & $\begin{array}{c}\text { Micro- } \\
\text { organism }\end{array}$ & $\begin{array}{l}\text { Organic/ } \\
\text { Inorganic }\end{array}$ \\
\hline \multirow{2}{*}{ River } & Normal & Normal & Normal & Normal & Normal \\
\hline & Flood & Very Bad & Very Bad & Very Bad & Very Bad \\
\hline \multicolumn{2}{|l|}{ Lake } & Normal & Very Bad & Normal & Normal \\
\hline \multicolumn{2}{|l|}{ Valley } & Very Bad & Normal & Normal & Good \\
\hline \multicolumn{2}{|c|}{ Groundwater } & Good & Normal & Very Bad & $\mathrm{Bad}$ \\
\hline \multicolumn{2}{|c|}{ Well/Spring Water } & Good & Normal & Very Bad & Bad \\
\hline \multicolumn{2}{|c|}{ Sea Water } & Normal & Normal & Good & Very Bad \\
\hline
\end{tabular}

According to the findings of the groundwater quality measurement network operation of the Ministry of Environment in 2010, 6.1\% (338) of 4,847 samples, at 4,998 points nationwide, exceeded the water quality standards. As shown in Fig. 2, the pollutants found in the groundwater in Korea were total colony, $\mathrm{NO}_{3}-\mathrm{N}$, total coliform, $\mathrm{Cl}^{-}$, and $\mathrm{pH}$. The specific harmful materials were trichloroethylene (TCE), tetrachloroethylene (PCE), As, $\mathrm{Cr}^{6+}$, and $\mathrm{Cd}$ in that order. Total colony and $\mathrm{NO}_{3}-\mathrm{N}$ are spread particularly widely nationwide, while TCE and PCE mostly pollute industrial and residential districts [10], [11].

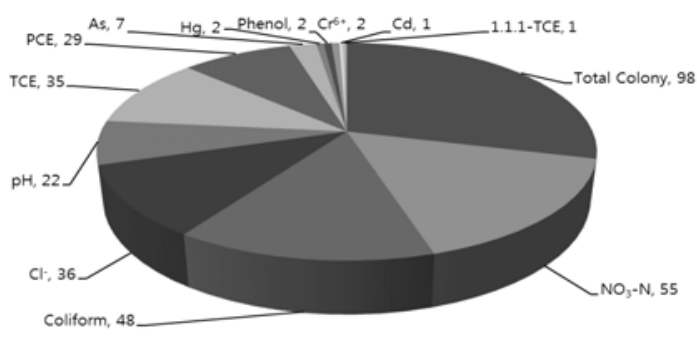

Fig. 2. Pollutants in the groundwater in Korea (2010).

\section{Applicable Process}

Because emergency water is generally supplied to the affected people in times of natural disasters, it is safe to expect that it will mostly be used for living purposes, such as washing, cleaning bathrooms, and drinking. Therefore, it was assumed that emergency water would be treated to the standards of water reclamation/reuse in case of water used for cleaning bathrooms and industrial purposes (e.g., cooling water), and to the standards of drinking water in case of water used for living and drinking. 
Moreover, because the supply of emergency water must be portable, the membrane filter treatment process was selected for each category, as shown in Table IV.

TABLE IV: RESPONSE PROCESS BY RAW WATER PROPERTY

\begin{tabular}{|c|c|c|c|c|c|}
\hline Category & Turbidity & $\begin{array}{c}\text { Pre. } \\
\text { treatment }\end{array}$ & $\begin{array}{c}\text { Primary } \\
\text { treatment }\end{array}$ & $\begin{array}{c}\text { Post- } \\
\text { treatment }\end{array}$ & Disinfection \\
\hline \multirow{2}{*}{$\begin{array}{c}1 \\
\text { (Tuthidity) }\end{array}$} & $>10 \mathrm{NTU}$ & $\begin{array}{l}\text { Coasulation } \\
\text { Adsopption }\end{array}$ & $\begin{array}{c}\text { MF/UF } \\
\text { PCF }\end{array}$ & . & $\begin{array}{l}\text { UV/ } \\
\mathrm{Cl}_{3}\end{array}$ \\
\hline & $40 \mathrm{NTU}$ & $\begin{array}{l}\text { Cosgulation } \\
\text { Adsorption }\end{array}$ & MFUF & - & $\begin{array}{l}\text { UV/ } \\
\mathrm{Cl}_{3}\end{array}$ \\
\hline \multirow{2}{*}{$\begin{array}{c}\text { II } \\
\text { (Turbidity+ } \\
\text { organic } \\
\text { inorganic }\end{array}$} & $>10 \mathrm{NTU}$ & $\begin{array}{l}\text { Coagulation } \\
\text { Adsoeption }\end{array}$ & $\begin{array}{l}\text { MF/UF } \\
\text { PCF } \\
\text { AOP }\end{array}$ & $\begin{array}{c}\text { NF/RO } \\
\text { AC }\end{array}$ & $\begin{array}{l}\mathrm{UV} / \\
\mathrm{Cl}_{2}\end{array}$ \\
\hline & $40 \mathrm{NTU}$ & $\begin{array}{l}\text { Coagulation } \\
\text { Adsopption }\end{array}$ & $\begin{array}{l}\text { MIUT } \\
\text { AOP }\end{array}$ & $\underset{A C}{\text { NF RO }}$ & $\begin{array}{l}\mathrm{UV} / \\
\mathrm{Cl} /\end{array}$ \\
\hline \multirow{2}{*}{$\begin{array}{c}\text { III } \\
\text { (Tusbidity + algae } \\
\text { + organc/ } \\
\text { morgamic) }\end{array}$} & C10NTU & $\begin{array}{l}\text { Coagulation } \\
\text { Adsopption }\end{array}$ & $\begin{array}{l}\text { MF/FF } \\
\text { PCF } \\
\text { AOP }\end{array}$ & $\begin{array}{c}\text { NFRO } \\
A C\end{array}$ & $\begin{array}{l}\mathrm{UV} / \\
\mathrm{Cl}_{2}\end{array}$ \\
\hline & $40 \mathrm{NTU}$ & $\begin{array}{l}\text { Cosgullation } \\
\text { Adsopption }\end{array}$ & $\begin{array}{l}\text { MFUF } \\
\text { AOP }\end{array}$ & $\begin{array}{c}\mathrm{NFRO} \\
\mathrm{AC}\end{array}$ & $\begin{array}{l}\mathrm{UV} / \\
\mathrm{Cl}_{3}\end{array}$ \\
\hline
\end{tabular}

A portable water treatment system needs to be installed in a container-like space so that it can be quickly transported to a specific area. Therefore, efficient internal space planning, miniaturization, and modularization of each unit, and effective mounting/dismounting of the module is needed to install the water treatment system in the limited available space and treat the water to conform to the World Health Organization (WHO) standards of drinking water quality.

\section{RESUlTS AND DISCUSSION}

This study developed a portable water treatment system in which the units are connected in the form of cassettes as shown in Fig. 3. The process was designed for $1.5 \mathrm{~m}^{3} /$ day capacity based on the water usage per person per day (around 335 LPCD (liters per capita per day)) so that it can be used as a small-scale water supply system when water service is interrupted. This capacity is sufficient for 100 people in normal times and satisfies the minimum water requirement for 2,200 people in times of disasters [12].

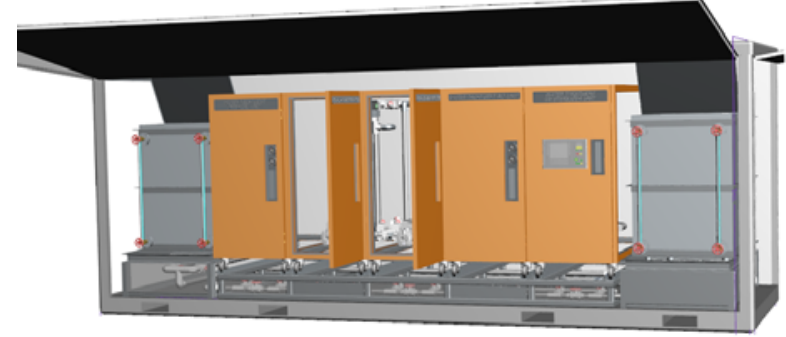

Fig. 3. Prototype of cassette-type water treatment package system.

TABLE V: SPECIFICATION OF MULTICHANNEL WATER QUALITY MEASUREMENT SYSTEM

\begin{tabular}{lccc}
\multicolumn{4}{c}{ MEASUREMENT SYSTEM } \\
\hline \hline Turbidity & Range & Resolution & Accuracy \\
Temperature & 0 to $1000 \mathrm{NTU}$ & $0.001 \mathrm{NTU}$ & $2 \%$ \\
$\mathrm{pH}$ & -5 to $75^{\circ} \mathrm{C}$ & $0.001{ }^{\circ} \mathrm{C}$ & $0.1^{\circ} \mathrm{C}$ \\
$\mathrm{Conductivity}$ & 0 to 14 & 0.001 & 0.2 \\
$\mathrm{Cl}^{-}$ & $0.01 \sim 100 \mathrm{mS}$ & $0.001 \mathrm{mS}$ & $0.5 \%$ \\
$\mathrm{NO}_{3}-\mathrm{N}$ & 0 to $1000 \mathrm{mg} / \mathrm{L}$ & $0.001 \mathrm{mg} / \mathrm{L}$ & $10 \%$ \\
\hline \hline
\end{tabular}

The developed portable water treatment system consisted of a control unit to regulate the system automatically, water treatment unit consisting of cassette-type units, and power unit for generating power, as shown in Fig. 4.

The control unit was designed to not only regulate the whole system automatically but also measure the water quality of the raw water and produced water through a multichannel water quality measurement system. Table V shows the detailed measurement range of the multichannel water quality measurement system.

The water treatment unit consisted of a membrane module and a sterilization module. It was designed to select an operational process automatically by measuring the turbidity, organic material, and concentration of ionic materials using the multichannel water quality measurement system, in accordance with the process categories listed in Table IV. It was also designed to be operated manually, so that water could be treated with a single cassette of the water treatment unit if required. Fig. 5 shows the scenario of selecting a process. The power unit consisted of a diesel power generation module and photovoltaic power generation module. For portability of the water treatment system, it was designed to be operable for $2.0 \mathrm{~h}$ or longer even in areas with no power availability. Currently, the purified water production and the water quality of the water treatment unit for each scenario is being verified, which will be followed by verification of the power unit.

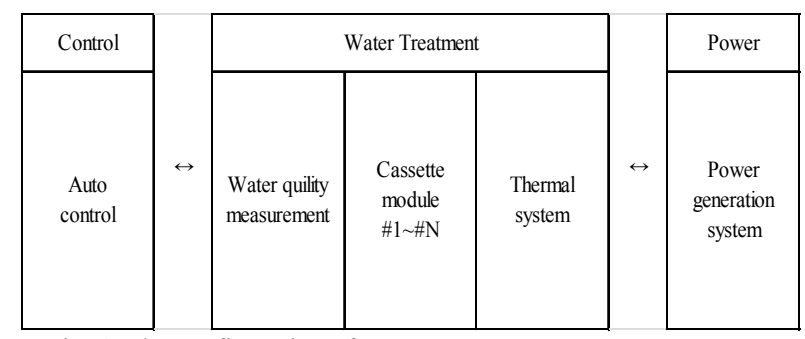

Fig. 4. The configuration of cassette-type water treatment system.

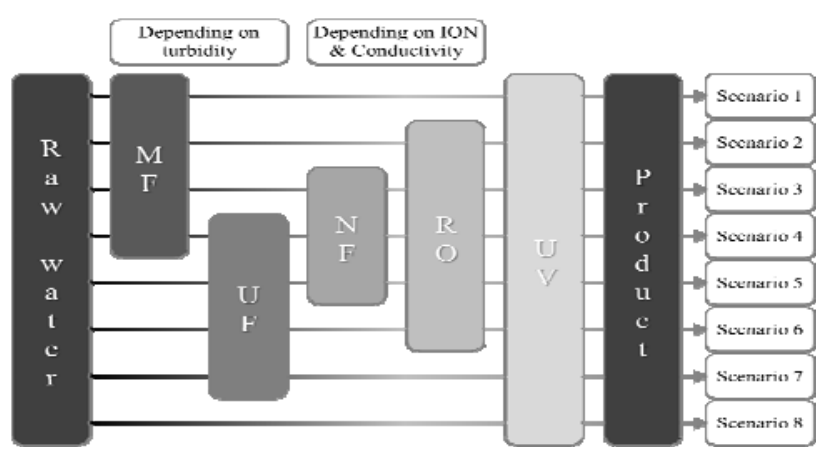

Fig. 5. The scenarios of process selection.

The cassette-type water treatment system developed in this study modularized water treatment equipment manufactured by various manufacturers for a specific space (cassette) so that a process could be structured selectively. Each module was designed to treat water independently, and featured self-diagnosis, automatic operation, intelligent process selection, and communication functions. We believe a competitive prototype was fabricated through these efforts.

\section{CONCLUSION}

1) A portable water treatment system was developed to supply emergency water during natural disasters. A water treatment module installed in a cassette form to support various raw water properties and combined 
with a multichannel water quality measurement system and interface made the system applicable under various conditions.

2) Water treatment units manufactured by various manufacturers were modularized for a specific space (cassette) so that a process could be structured selectively according to the requirement. The system was designed to be manually operated so that water can be treated with a single cassette of the water treatment unit if required.

3) Compared with the existing emergency water supply systems, the proposed system could intelligently select an operational process according to raw water properties, and the power unit for self-generation was designed to be in a cassette form so that it could be operated for $3 \mathrm{~h}$ or longer even under the conditions of no power availability. Therefore, the system can be used not only in times of natural disasters but also in case of interruption to water services.

\section{ACKNOWLEDGMENTS}

This research was supported by Korea Ministry of Environment as "The Eco-Innovation Project (Global Top Project)". (GT-SWS-11-01-008-0)

This research was supported by a grant from a Strategic Research Project (20140030-1-1) funded by Korea Institute of Construction Technology.

\section{REFERENCES}

[1] W. Y. Jung and D. H. Hwang, "Feasibility study on the designation of a special disaster area by considering the climate extreme value," Journal of the Korean Society of Hazard Mitigation, vol. 12, no. 5, pp. 135-141, 2012.

[2] K. H. Oh, W. Y. Jung, and M. K. Park, "A study on the declaration criteria of special disaster zone of the man-made disaster," Journal of National Institute for Disaster Prevention, vol. 9, no. 2, pp. 142-145, 2007.

[3] Y. H. Lee, "Study on emergency water supply alternatives in cut off water supply-prone island area," M.S. thesis, Dept. Environmental
Engineering, Kyungpook National University, Kyungpook, Korea, 2013.

[4] Y. J. Lee, J. H. Lee, S. S. Byun, and J. E. Lee, "Improving the PR system of the disaster management-contents analysis of monthly publication of the disaster analysis and prospect in NEMA," Journal of the Korea Contents Association, vol. 11, no. 4, pp. 338-346, 2011.

[5] J. E. Lee, "What's the disaster recovery? Types and pre-impact plan of recovery," Journal of the Korea Contents Association, vol. 11, no. 10, pp. 267-273, 2011.

[6] W. Kwon, "The analysis about the special quality of disaster management and environment factor for the efficient disaster management," Journal of Korean Institute of Fire Science \& Engineering, vol. 20, no. 3, pp. 118-126, 2006.

[7] J. H. Kim, I. C. Lee, and H. S. Lee, "A numerical prediction of pollutant material budget during the flood and dry season in gwangyang bay," Journal of Korean Society of Coastal and Ocean Engineers, vol. 23, no. 4, pp. 25-31, 2009.

[8] T. K. Lee, S. H. Chae, S. S. Kim, S. S. In, J. H. Kim, and N. S. Park, "Establishment of methodology for estimating an emergency water," Journal of Korean Society of Water and Wastewater, vol. 26, no. 3, 361-372, 2012.

[9] Y. H. Lee, W. H. Hong, and J. S. Lee, "The vulnerability assessment of water supply through the analysis of emergency water shortage in cut off water supply-prone island area," Journal of Korean Society of Environmental Engineers, vol. 30, no. 1, pp. 253-260, 2014.

[10] J. K. Park, R. H. Kim, J. Y. Lee, D. H. Choi, and T. D. Kim, "Evaluation of status of groundwater quality monitoring network of Korea: Implications for improvement," Journal of Soil and Groundwater Environment, vol. 12, no. 6, pp. 92-99, 2007.

[11] I. S. Kim, J. Y. Lee, and S. I. Choi, "A study on the characteristic of the groundwater quality in Seoul," Journal of Soil and Groundwater Environment, vol. 9, no. 2, pp. 54-63, 2004.

[12] EPA, Planning for an Emergency Drinking Water Supply, 2011.

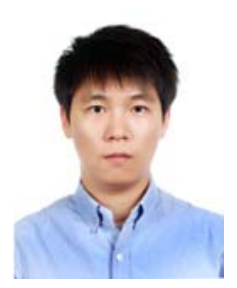

Ju Suk An received his B.A. in environmental engineering from Yonsei University, Seoul, Korea in 2010. He received his M.A. in environmental engineering from Yonsei University, Seoul, Korea in 2012. Now. He is present a researcher in Korea Institute of Construction Technology (KICT), Goyang-si, Korea.

Ju Suk An is a researcher at Korea Institute of Construction Technology (KICT), Korea. He was born on August 20, 1985, in Inchon, Korea. His early research focused on water chemistry and water treatment process using membrane; his current interests and research is water treatment package system for emergency. 